\title{
Pulmonary artery resuscitation for isolated ductal origin of a pulmonary artery
}

\author{
Carlos M. Mery, MD, MPH, ${ }^{\mathrm{a}}$ Kimberly M. Molina, MD, ${ }^{\mathrm{b}}$ Rajesh Krishnamurthy, MD, \\ Charles D. Fraser, Jr, MD, ${ }^{a}$ and Henri Justino, MD $^{\mathrm{d}}$
}

Objective: Ductal origin of a pulmonary artery (DOPA) is commonly misdiagnosed as agenesis of a pulmonary artery (PA), which may result in inadequate treatment. The objective is to describe the results of resuscitation of unilateral DOPA.

Methods: This study is a retrospective review of all patients with unilateral DOPA who underwent PA resuscitation at Texas Children's Hospital from 1993 to 2012. Patients with other cardiac or contralateral lung anomalies were excluded.

Results: Ten patients, median age 2 years (range, 3 days to 9 years), with unilateral DOPA were included. Symptoms were present in 6 patients. Cardiac catheterization was performed in all and showed a patent duct or a ductal stump in most patients and a small PA on wedge angiography of the pulmonary veins. Two patients underwent single-stage centralization. The other 8 underwent ductal stenting $(\mathrm{n}=2)$ or a systemic-to-PA shunt $(n=6)$ as the first stage before centralization. The 2 patients with ductal stenting developed pulmonary edema. The 2 patients with a cryopreserved vein shunt developed early thrombosis requiring reintervention. Nine patients have undergone centralization. Six patients have required further interventional procedures. There have been no deaths. Symptoms and lung hypoplasia have improved in all patients. Median relative lung perfusion at follow-up was $26 \%$ (range, $12 \%-46 \%$ ) with significant improvement in the size of the affected PA.

Conclusions: PA resuscitation is effective at restoring flow to the affected lung resulting in improved diameter of the PA, lung growth, and resolution of symptoms. PA resuscitation should be considered in all children with DOPA, including those beyond infancy. (J Thorac Cardiovasc Surg 2014;148:2235-44)

Supplemental material is available online.

Ductal origin of a pulmonary artery (DOPA) is an uncommon congenital cardiovascular anomaly occurring as a solitary malformation or in association with other congenital heart anomalies, such as tetralogy of Fallot or heterotaxy syndrome. ${ }^{1,2}$ In DOPA, 1 or both pulmonary arteries (PA) arise from a ductus arteriosus or a persistent fifth aortic arch, a ductal variant. Bilateral DOPA, where each PA arises from a separate ductus, is seen with

\footnotetext{
From the Division of Congenital Heart Surgery, ${ }^{\text {a }}$ Texas Children's Hospital; Michael E. DeBakey Department of Surgery, Baylor College of Medicine, Houston, Tex; Section of Pediatric Cardiology, ${ }^{\mathrm{b}}$ Primary Children's Medical Center, University of Utah, Salt Lake City, Utah; Division of Pediatric Radiology, ${ }^{\mathrm{c}}$ Lillie Frank Abercrombie Section of Pediatric Cardiology, ${ }^{\mathrm{d}}$ Texas Children's Hospital, Baylor College of Medicine, Houston, Tex.

Disclosures: H. Justino has acted as a consultant for St Jude Medical, Inc, St Paul, Minn. All other authors have nothing to disclose with regard to commercial support.

Received for publication Aug 17, 2013; revisions received Nov 13, 2013; accepted for publication Nov 29, 2013; available ahead of print Feb 4, 2014.

Address for reprints: Carlos M. Mery, MD, MPH, Congenital Heart Surgery, Texas Children's Hospital, 6621 Fannin St, 19345H, Houston, TX 77030-2399 (E-mail: cmmery@texaschildrens.org). $0022-5223 / \$ 36.00$

Copyright (c) 2014 by The American Association for Thoracic Surgery http://dx.doi.org/10.1016/j.jtcvs.2013.11.041
}

pulmonary atresia and presents in the neonatal period with profound hypoxia if both ducts close. On the contrary, unilateral DOPA can occur with an otherwise normally formed heart, such that the affected PA receives blood from a ductus while the contralateral PA is normally connected to the main PA. On postnatal ductal closure, only the affected PA ceases to receive flow. Because the remainder of the heart is normally formed, this does not result in cyanosis, and can therefore escape detection in the neonatal period. Failure to treat this condition may result in hypoplasia of the associated PA, compensatory development of aortopulmonary collaterals to the affected lung, increased susceptibility to pulmonary infections, pulmonary hemorrhage, as well as thoracic asymmetry caused by asymmetric lung volumes, leading to scoliosis. ${ }^{3-8}$

After closure of the ductus arteriosus, the absence of flow to the affected lung and the nonvisualization of the affected proximal PA on imaging studies often leads to the erroneous conclusion that there is agenesis or absence of the affected PA. Consequently, patients may not be offered appropriate corrective procedures.

Our institution has been proactive in identifying any remnant of the abnormal PA with cross-sectional imaging or cardiac catheterization and resuscitating the abnormal PA to avoid lung hypoplasia, either with a single or staged approach. The goal of this study is to describe 


$$
\begin{aligned}
\text { Abbreviations and Acronyms } \\
\text { BT }=\text { Blalock-Taussig } \\
\text { CT }=\text { computed tomography } \\
\text { DOPA }=\text { ductal origin of a pulmonary artery } \\
\text { LPA }=\text { left pulmonary artery } \\
\text { MPA }=\text { main pulmonary artery } \\
\text { MRI }=\text { magnetic resonance imaging } \\
\text { PA }=\text { pulmonary artery } \\
\text { RPA }=\text { right pulmonary artery }
\end{aligned}
$$

our experience on the diagnosis and resuscitation of unilateral DOPA and the outcomes associated with this approach.

\section{METHODS}

All patients with isolated DOPA treated from 1993 to 2012 at Texas Children's Hospital were included in the study. Patients were identified from our cardiology, cardiac surgery, and radiology databases. Patients with additional congenital heart defects were excluded from this study in order to be able to arrive at a meaningful comparison of posttreatment lung perfusion between the lung with DOPA and the congenitally normal contralateral lung. One patient with a left DOPA managed in 1997 was excluded because of lack of information about the details of the patient, procedures performed, and follow-up.

Data were collected by reviewing clinic notes, operative notes, discharge summaries, echocardiographic and radiologic images and reports, and documented telephone encounters. The data collected included age and symptoms at presentation, diagnostic information, type and details of corrective procedures performed, complications, and outcomes including relative perfusion and growth of the affected PA. Long-term follow-up information, including current physical examination and symptoms, was obtained whenever possible. All data are presented as percentages, means with standard deviation, medians, and ranges, as appropriate. The study was approved by the Baylor College of Medicine Institutional Review Board.

\section{RESULTS \\ Patients}

During the study period, there were 10 patients with DOPA and an otherwise normal heart (Table 1). Median age at diagnosis was 2 years (range, 3 days to 9 years). Nine patients had DOPA affecting the lung contralateral to the aortic arch: right lung/left arch $(n=7)$, left lung/right arch $(n=2)$, and 1 patient had left DOPA in the setting of a left-dominant double aortic arch. Other abnormalities encountered included a history of aortic coarctation requiring repair via a left thoracotomy in a patient with ductal origin of the right PA (RPA) (patient 5), laryngeal webs and microdeletion 22q11 in a patient with ductal origin of the left PA (LPA) and a right arch with mirror image branching (patient 9), and history of Hirschprung disease requiring an anal pull-through as a neonate (patient 10).

\section{Clinical Presentation}

Symptoms were present at the time of diagnosis in 6 patients; 4 patients had recurrent respiratory infections and 3 patients had increased work of breathing. No patient had hemoptysis at presentation. Delay in diagnosis was not infrequent. One patient (patient 4) had frequent respiratory infections from 14 months of age and was not diagnosed until he was 3 years old and a chest radiograph performed for fever showed right lung hypoplasia. Another patient (patient 5) had poor exercise tolerance for 6 months before diagnosis. A 7-year old patient (patient 7) had had recurrent respiratory infections since birth and had been given the diagnosis of reactive airway disease; the correct diagnosis was made after a chest radiograph showed right lung hypoplasia. Patient 6 had a fever episode at an outside institution. Workup erroneously revealed agenesis of the RPA and the family was told there were no therapeutic options. The correct diagnosis was made 4 months later after the family sought further care. Patient 9 was diagnosed at birth with possible right aortic arch and aortopulmonary collaterals supplying the left lung. The correct diagnosis was only made at 4 years of age after the parent requested chest computed tomography (CT) to rule out aortic arch abnormalities given the recent diagnosis of 22q11 microdeletion and its possible association with arch abnormalities. Patient 10 was diagnosed at birth with a possible PA sling and cardiac magnetic resonance imaging (MRI) was recommended. He was lost to follow-up until referred back for MRI at 4 years of age.

The findings on chest radiographs that raised initial suspicion and led to further studies included hypoplasia of the affected lung with decreased pulmonary vascular markings and mediastinal displacement $(\mathrm{n}=3)$, and haziness of the involved lung $(\mathrm{n}=1)$. All 5 older patients in the series (3-9 years of age) had hypoplasia of the involved lung on chest radiographs. Echocardiographic images showed a main PA segment with a single branching PA. Cross-sectional imaging was used to confirm the diagnosis in 7 patients; 4 patients underwent MRI and 3 patients had CT. These studies showed an absent mediastinal segment of the abnormal PA in all cases. In 1 case, the distal PA was visualized in the hilum in a late phase of imaging after receiving blood supply from 2 aortopulmonary collaterals (patient 10, Figure 1).

All patients underwent cardiac catheterization (Figure 1). Mean pulmonary pressure in the normal PA was $16.9 \pm 3.5$ $\mathrm{mm} \mathrm{Hg}$ for the 8 patients who had available pulmonary pressures; only 1 patient had pulmonary hypertension as defined by a mean pressure of $25 \mathrm{~mm} \mathrm{Hg}$ or higher. In 8 patients, a patent ductus $(\mathrm{n}=1)$ or a small stump $(\mathrm{n}=7)$ was observed at the base of the brachiocephalic artery, indicating the ductal origin of the abnormal PA. One patient with a left aortic arch had a stump visualized at the distal ascending aorta and the patient with a double aortic arch had a stump at the bifurcation of the distal ascending aorta, likely indicating a persistent fifth aortic arch in both cases. Pulmonary venous wedge angiography was used to 
TABLE 1. Clinical information for patients with isolated ductal origin of a pulmonary artery treated with resuscitation of the pulmonary artery

\begin{tabular}{|c|c|c|c|c|c|c|c|}
\hline Patient & Age & $\begin{array}{c}\text { DOPA side } \\
\text { (arch sidedness) }\end{array}$ & Clinical presentation & First stage & Second stage & $\begin{array}{c}\text { Further } \\
\text { interventions }\end{array}$ & Results \\
\hline 1 & $10 \mathrm{mo}$ & Left (right arch) & $\begin{array}{l}\text { Pneumonia } \\
\text { Echo: left ductus and } \\
\text { DOPA } \\
\text { Cath: Small patent left } \\
\text { ductus from the left } \\
\text { brachiocephalic } \\
\text { artery with ductal } \\
\text { origin of LPA }\end{array}$ & $\begin{array}{l}\text { Classic left BT } \\
\text { shunt (1 y) }\end{array}$ & $\begin{array}{l}\text { Anastomosis of } \\
\text { proximal left } \\
\text { subclavian to MPA } \\
\text { ( } 20 \text { mo after first } \\
\text { stage) }\end{array}$ & $\begin{array}{l}\text { LPA stent and dilation } \\
\text { for LPA stenosis (10 } \\
\text { and } 15 \text { mo after } \\
\text { surgery) }\end{array}$ & $\begin{array}{l}\text { Asymptomatic } 2 \text { y } \\
\text { after surgery } \\
\text { Good development of } \\
\text { LPA ( } 8 \text { mm vs } 10 \\
\text { mm RPA) } 2 \text { y after } \\
\text { second stage } \\
\text { Perfusion scan: } 12 \% \\
\text { left (before LPA } \\
\text { dilation) }\end{array}$ \\
\hline 2 & $3 \mathrm{mo}$ & Right (left arch) & $\begin{array}{l}\text { Murmur at birth } \\
\text { Cath: dimple on right } \\
\text { brachiocephalic } \\
\text { artery, small RPA } \\
\text { on wedge injection, } \\
\text { small collaterals }\end{array}$ & $\begin{array}{l}\text { RPA centralization } \\
\text { with pericardial } \\
\text { roll }(6 \mathrm{mo})\end{array}$ & & & $\begin{array}{l}\text { Asymptomatic } 1 \text { mo } \\
\text { after surgery. No } \\
\text { long-term follow- } \\
\text { up }\end{array}$ \\
\hline 3 & $3 d$ & Right (left arch) & $\begin{array}{l}\text { Respiratory distress at } \\
\text { birth } \\
\text { Echo: no visualization } \\
\text { of RPA } \\
\text { Cath: dimple on right } \\
\text { brachiocephalic art, } \\
\text { normal RPA on } \\
\text { wedge injection }\end{array}$ & Ductal stent (10 d) & $\begin{array}{l}\text { RPA unifocalization } \\
\text { with pericardial roll } \\
(1 \mathrm{mo} \text { after first } \\
\text { stage })\end{array}$ & & $\begin{array}{l}\text { Pulmonary } \\
\text { hypertension after } \\
\text { ductal stent } \\
\text { Asymptomatic } 2 \text { y } \\
\text { after surgery } \\
\text { Smaller RPA }(4.5 \mathrm{~mm}) \\
\text { than LPA }(9.5 \mathrm{~mm}) \\
1 \text { y after second } \\
\text { stage } \\
\text { Perfusion scan: } 31 \% \\
\text { right }(2 \text { mo after } \\
\text { second stage })\end{array}$ \\
\hline 4 & $3 y$ & Right (left arch) & $\begin{array}{l}\text { Frequent respiratory } \\
\text { infections } \\
\text { Chest radiograph: } \\
\text { right lung } \\
\text { hypoplasia } \\
\text { MRI: RPA not } \\
\text { visualized } \\
\text { Cath: no RPA } \\
\text { visualized on PA } \\
\text { injection, small } \\
\text { RPA on wedge } \\
\text { injection, no dimple }\end{array}$ & $\begin{array}{l}\text { RPA centralization } \\
\text { with pericardial } \\
\text { roll }(5 \mathrm{y})\end{array}$ & & $\begin{array}{l}\text { Angioplasty and stent } \\
\text { of pericardial roll } \\
\text { due to obstruction } \\
6 \text { mo after surgery. } \\
\text { Further dilation of } \\
\text { stent }\end{array}$ & $\begin{array}{l}\text { Asymptomatic } 7 \text { y } \\
\text { after surgery } \\
\text { Moderate } \\
\text { development of } \\
\text { RPA ( } 8.6 \mathrm{~mm},-2.6 \\
\mathrm{Z} \text { score) } 6 \mathrm{y} \text { after } \\
\text { surgery } \\
\text { Perfusion scan: } 26 \% \\
\text { right (6 y after } \\
\text { surgery) }\end{array}$ \\
\hline 5 & $9 y$ & Right (left arch) & $\begin{array}{l}\text { History of aortic } \\
\text { coarctation repair at } \\
1 \mathrm{y} \\
\text { Exercise intolerance } \\
\text { for } 6 \text { mo, headaches } \\
\text { Chest radiograph: } \\
\text { right lung } \\
\text { hypoplasia } \\
\text { CT: no evidence of } \\
\text { RPA } \\
\text { Cath: dimple on right } \\
\text { brachiocephalic, no } \\
\text { RPA from MPA, } \\
\text { tiny isolated RPA } \\
\text { on wedge injection }\end{array}$ & $\begin{array}{l}\text { RITA to RPA shunt } \\
\text { (9 y) }\end{array}$ & $\begin{array}{l}\text { RPA unifocalization } \\
\text { with } 8 \text { mm Gore- } \\
\text { Tex interposition } \\
\text { graft at outside } \\
\text { institution ( } 22 \text { mo } \\
\text { after first stage) }\end{array}$ & & $\begin{array}{l}\text { Asymptomatic } 3 \text { y } \\
\text { after surgery } \\
\text { (followed at outside } \\
\text { institution) } \\
\text { Adequate flow to both } \\
\text { PAs according to } \\
\text { echocardiogram } \\
\text { reports }\end{array}$ \\
\hline
\end{tabular}


TABLE 1. Continued

\begin{tabular}{|c|c|c|c|c|c|c|c|}
\hline Patient & Age & $\begin{array}{c}\text { DOPA side } \\
\text { (arch sidedness) }\end{array}$ & Clinical presentation & First stage & Second stage & $\begin{array}{c}\text { Further } \\
\text { interventions }\end{array}$ & Results \\
\hline 6 & $5 \mathrm{wk}$ & Right (left arch) & $\begin{array}{l}\text { Chest radiograph for } \\
\text { fever showed hazy } \\
\text { right lung } \\
\text { CT: no RPA } \\
\text { visualized, small } \\
\text { right lung } \\
\text { Cath: dimple on right } \\
\text { brachiocephalic } \\
\text { artery, normal RPA } \\
\text { on wedge injection }\end{array}$ & $\begin{array}{l}\text { Modified right BT } \\
\text { shunt ( } 3 \mathrm{~mm} \\
\text { cryopreserved } \\
\text { GSV) (6 mo) } \\
\text { Postoperative shunt } \\
\text { thrombosis } \\
\text { requiring revision } \\
\text { and anticoagulation } \\
\text { Angioplasty of BT } \\
\text { shunt for stenosis } \\
\text { and thrombus after } \\
\text { first stage }\end{array}$ & $\begin{array}{l}\text { RPA unifocalization } \\
\text { with anterior } \\
\text { pericardial } \\
\text { augmentation (9 mo } \\
\text { after first stage) }\end{array}$ & & $\begin{array}{l}\text { Asymptomatic } 3 \text { y } \\
\text { after surgery } \\
\text { Cath } 8 \text { mo after } \\
\text { surgery with well } \\
\text { developed distal } \\
\text { vasculature and } \\
\text { good development } \\
\text { of RPA ( } 8 \mathrm{~mm} \text { vs } 10 \\
\text { mm LPA). Some } \\
\text { stenosis of RPA } \\
\text { Perfusion: } 46 \% \text { right } \\
\text { (3 y after surgery) }\end{array}$ \\
\hline 7 & $7 y$ & Right (left arch) & $\begin{array}{l}\text { Frequent respiratory } \\
\text { infections } \\
\text { CT: small right lung, } \\
\text { no RPA visualized, } \\
\text { dimple on right } \\
\text { brachiocephalic } \\
\text { artery } \\
\text { Cath: Dimple on right } \\
\text { brachiocephalic } \\
\text { artery, no RPA } \\
\text { visualized, small } \\
\text { RPA ( } 3.9 \text { mm) on } \\
\text { wedge injection }\end{array}$ & $\begin{array}{l}\text { Modified right BT } \\
\text { shunt (5 mm Gore- } \\
\text { Tex graft) (7 y) }\end{array}$ & $\begin{array}{l}\text { RPA centralization } \\
\text { with pericardial roll } \\
(26 \text { mo after first } \\
\text { stage })\end{array}$ & $\begin{array}{l}\text { Angioplasty and } \\
\text { stenting of RPA } 6 \\
\text { mo after second } \\
\text { stage }\end{array}$ & $\begin{array}{l}\text { Asymptomatic } 2 \text { y } \\
\text { after surgery } \\
\text { Improvement in } \\
\text { respiratory } \\
\text { infections } \\
\text { Good size RPA ( } 8.5 \\
\text { mm, }-2 \mathrm{Z} \text { score) } \\
\text { compared with } \\
\text { dilated LPA ( } 20 \\
\text { mm, }+4.7 \mathrm{Z} \text { score) } \\
4 \text { mo after surgery } \\
\text { Improved size of right } \\
\text { lung } \\
\text { Perfusion: } 26 \% \text { right } \\
\text { (2 y after surgery) }\end{array}$ \\
\hline 8 & $6 \mathrm{wk}$ & Left (double arch) & $\begin{array}{l}\text { Vascular ring on fetal } \\
\text { echo } \\
\text { MRA: left-dominant } \\
\text { double arch, absent } \\
\text { LPA, dimple at } \\
\text { ascending aorta } \\
\text { Cath: hypoplastic LPA } \\
\text { (2.9 mm) seen with } \\
\text { wedge injection, } \\
\text { small persistent } \\
\text { fifth aortic arch }\end{array}$ & $\begin{array}{l}\text { Ductal stent via right } \\
\text { carotid (2 mo) }\end{array}$ & $\begin{array}{l}\text { LPA centralization } \\
\text { with anterior } \\
\text { pericardial } \\
\text { augmentation, stent } \\
\text { removal, division of } \\
\text { right arch }\end{array}$ & $\begin{array}{l}\text { Postoperative LPA } \\
\text { stent due to kink, } \\
\text { repeat balloon } \\
\text { angioplasty } 4 \text { mo } \\
\text { later }\end{array}$ & $\begin{array}{l}\text { Seizures and } \\
\text { pulmonary edema/ } \\
\text { reperfusion injury } \\
\text { after ductal stent } \\
\text { Asymptomatic } 2 \mathrm{y} \\
\text { after surgery } \\
\text { Small LPA ( } 4.4 \mathrm{~mm}) \\
\text { compared with RPA } \\
\text { ( } 8.1 \mathrm{~mm}) 4 \text { mo after } \\
\text { surgery } \\
\text { Perfusion: } 30 \% \text { left } \\
\text { (20 mo after } \\
\text { surgery) }\end{array}$ \\
\hline 9 & $4 y$ & Left (right arch) & $\begin{array}{l}\text { History of 22q11 } \\
\text { deletion, laryngeal } \\
\text { webs } \\
\text { Echo as infant for LV } \\
\text { hypertrophy on } \\
\text { ECG with? right } \\
\text { arch and AP } \\
\text { collaterals to left } \\
\text { lung; followed } \\
\text { clinically } \\
\text { CT at } 4 \text { y: no } \\
\text { visualization LPA, } \\
\text { dimple left } \\
\text { brachiocephalic } \\
\text { artery, left lung } \\
\text { hypoplasia }\end{array}$ & $\begin{array}{l}\text { Modified left BT shunt } \\
(4 \mathrm{~mm} \\
\text { cryopreserved } \\
\text { GSV) }(4 \mathrm{y}) \\
\text { Postoperative shunt } \\
\text { occlusion and } \\
\text { thrombosis } \\
\text { requiring revision } \\
\text { and anticoagulation }\end{array}$ & $\begin{array}{l}\text { LPA centralization } \\
\text { with anterior } \\
\text { pericardial } \\
\text { augmentation, } \\
\text { division of BT } \\
\text { shunt }\end{array}$ & $\begin{array}{c}\text { Balloon angioplasty of } \\
\text { left lower lobe PA } 4 \\
\text { mo after surgery }\end{array}$ & $\begin{array}{l}\text { Asymptomatic } 2 \text { y } \\
\text { after surgery } \\
\text { Significant growth of } \\
\text { LPA ( } 8.8 \mathrm{~mm},-1 \mathrm{Z} \\
\text { score), smaller than } \\
\text { RPA ( } 12.1 \mathrm{~mm},+3 \\
\text { Z score) } \\
\text { Perfusion: } 12 \% \text { left } \\
\text { (4 mo after surgery) }\end{array}$ \\
\hline
\end{tabular}


TABLE 1. Continued

\begin{tabular}{|c|c|c|c|c|c|c|c|}
\hline Patient & Age & $\begin{array}{c}\text { DOPA side } \\
\text { (arch sidedness) }\end{array}$ & Clinical presentation & First stage & Second stage & $\begin{array}{c}\text { Further } \\
\text { interventions }\end{array}$ & Results \\
\hline 10 & $4 y$ & Right (left arch) & $\begin{array}{l}\text { Cath: no flow from } \\
\text { MPA to LPA, } \\
\text { dimple left } \\
\text { brachiocephalic } \\
\text { artery, small LPA } \\
\text { (3.5 mm) on wedge } \\
\text { injection, multiple } \\
\text { AP collaterals } \\
\text { History of } \\
\text { Hirschprung } \\
\text { disease status post } \\
\text { anal pull-through at } \\
1 \text { mo } \\
\text { Shortness of breath } \\
\text { and murmur } \\
\text { MRI: no mediastinal } \\
\text { RPA, distal RPA } \\
\text { filled by } 2 \text { AP } \\
\text { collaterals, right } \\
\text { lung hypoplasia, } \\
\text { dimple right } \\
\text { brachiocephalic } \\
\text { artery } \\
\text { Cath: dimple at right } \\
\text { brachiocephalic } \\
\text { artery, multiple } \\
\text { right AP collaterals, } \\
\text { small ( } 6 \text { mm) RPA } \\
\text { via wedge injection }\end{array}$ & $\begin{array}{l}\text { Modified right BT } \\
\text { shunt (5 mm Gore- } \\
\text { Tex graft) (5 y) }\end{array}$ & & & $\begin{array}{l}\text { Asymptomatic } 2 \text { y } \\
\text { after first stage } \\
\text { Awaiting second stage }\end{array}$ \\
\hline
\end{tabular}

DOPA, Ductal origin of a pulmonary artery; Echo, echocardiography; Cath, catheterization; LPA, left pulmonary artery; $B T$, Blalock-Taussig; $M P A$, main pulmonary artery; $R P A$, right pulmonary artery; $M R I$, magnetic resonance imaging; $P A$, pulmonary artery; $C T$, computed tomography; RITA, right internal thoracic artery; GSV, greater saphenous vein; $M R A$, magnetic resonance angiography; $L V$, left ventricular; $E C G$, electrocardiogram; $A P$, aortopulmonary.

visualize the isolated PA in all cases except for a patient with a patent ductus in which the LPA was seen to arise from the ductus by direct injection (patient 1). The isolated PA was considered hypoplastic in 7 cases (median diameter, $3.4 \mathrm{~mm}$; range, $2-4.5 \mathrm{~mm}$ ) and normal in 3 . Aortopulmonary collaterals were seen in 3 cases, and represented enlarged bronchial arteries and other minor collaterals.

\section{Management and Short-Term Complications}

The management strategy of this cohort is illustrated in Figure E1. Two of the patients with DOPA underwent a single-stage repair consisting of a pericardial roll graft placed between the main PA (MPA) and the RPA (patients 2 and 4). The first patient was operated on at 6 months of age and was lost to follow-up after the immediate postoperative visit, thus long-term patency of the graft is unknown. The second patient managed with a single-stage repair was operated on at 5 years of age and developed complete occlusion of the graft 6 months later. The graft was successfully recanalized and stented at catheterization. Further dilation of the stent was required as the patient continued to grow.

A staged repair was used in 8 patients to incite growth of the hypoplastic PA by creating a communication between the systemic circulation and the affected PA before centralization. The first stage consisted of recanalization and stenting of the occluded ipsilateral ductus in 2 patients and creation of a surgical systemic-to-PA shunt in 6 patients. Surgical shunts included a classic Blalock-Taussig (BT) shunt in a patient early in our series, a right internal thoracic artery to RPA anastomosis in another patient, and modified BT shunts in 4 patients. Modified BT shunts were constructed with either reversed cryopreserved greater saphenous veins $(\mathrm{n}=2)$ or with polytetrafluoroethylene grafts $(n=2)$ (Gore-Tex; W. L. Gore \& Associates, Inc., Flagstaff, Ariz).

The 2 patients who underwent ductal stenting as the first stage (patients 3 and 8 ) developed severe pulmonary edema in the affected lung after stenting. Both patients were 

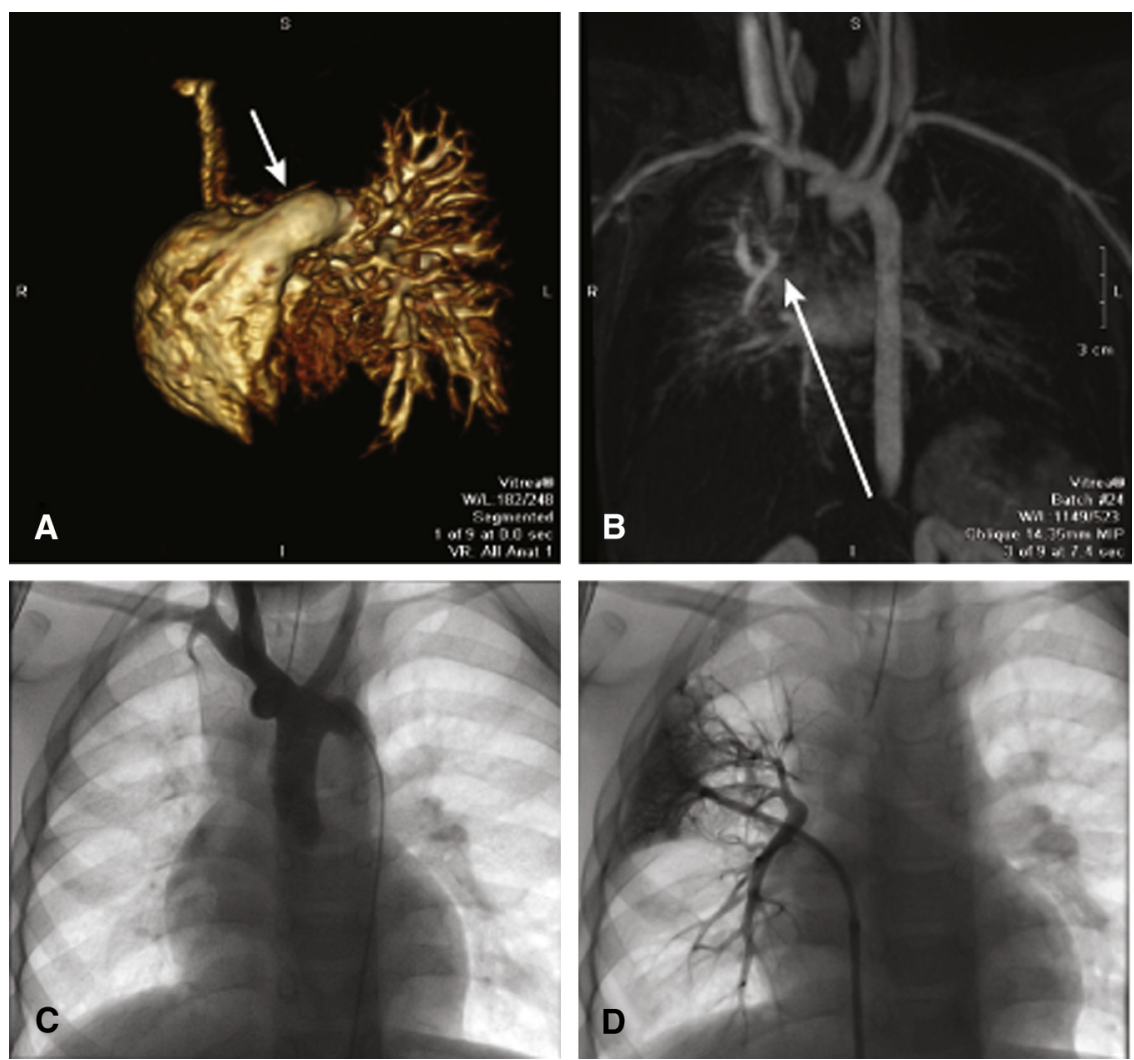

FIGURE 1. A 4-year-old boy with ductal origin of the right pulmonary artery (PA) and aortopulmonary collaterals feeding into the distal PA. A and B, Magnetic resonance imaging; $\mathrm{C}$ and D, cardiac catheterization. A, Absence of the mediastinal portion of the right PA from the main PA (arrow) is evident. $\mathrm{B}$, A small right PA (arrow) ending approximately $1 \mathrm{~cm}$ from the mediastinal pleura and fed by aortopulmonary collaterals is visible. Cardiac catheterization shows: C, a ductal stump at the base of the right brachiocephalic artery; and D, a small distal right PA with a blind end as visualized from retrograde pulmonary venous wedge injection of contrast.

managed with endotracheal intubation and positive pressure ventilation and had complete resolution of the pulmonary edema in 48 to 72 hours.

The 2 patients who underwent creation of a modified BT shunt with cryopreserved saphenous vein graft because of the small size of the PA (patients 6 and 9) developed thrombosis of the shunt within 3 days. Thrombosis of the shunt was treated by surgical thrombectomy and shunt revision, in addition to anticoagulation. One of these patients was found to have partial obstruction and thrombus at the pulmonary end of the revised saphenous vein graft shunt on cardiac catheterization 3 months later. He underwent balloon angioplasty of this area with improvement in the caliber of the distal anastomosis.

Of the 8 patients assigned to a 2 -stage approach, the final stage of repair has been completed in 7 patients by
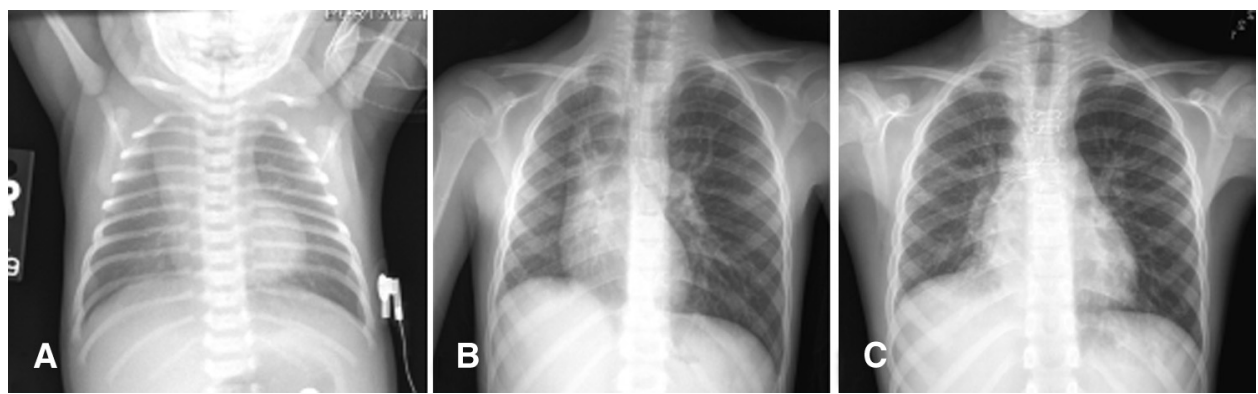

FIGURE 2. Serial chest radiographs in a patient with late diagnosis of ductal origin of the right pulmonary artery. A, The patient had normal appearance of the lung as a newborn infant. B, A chest radiograph at 7 years of age showed severe hypoplasia of the right lung with significant mediastinal shift; he was subsequently diagnosed with ductal origin of the right pulmonary artery. C, A radiograph of the same patient after staged resuscitation of the right pulmonary artery demonstrating significant improvement in the size of the right lung. 


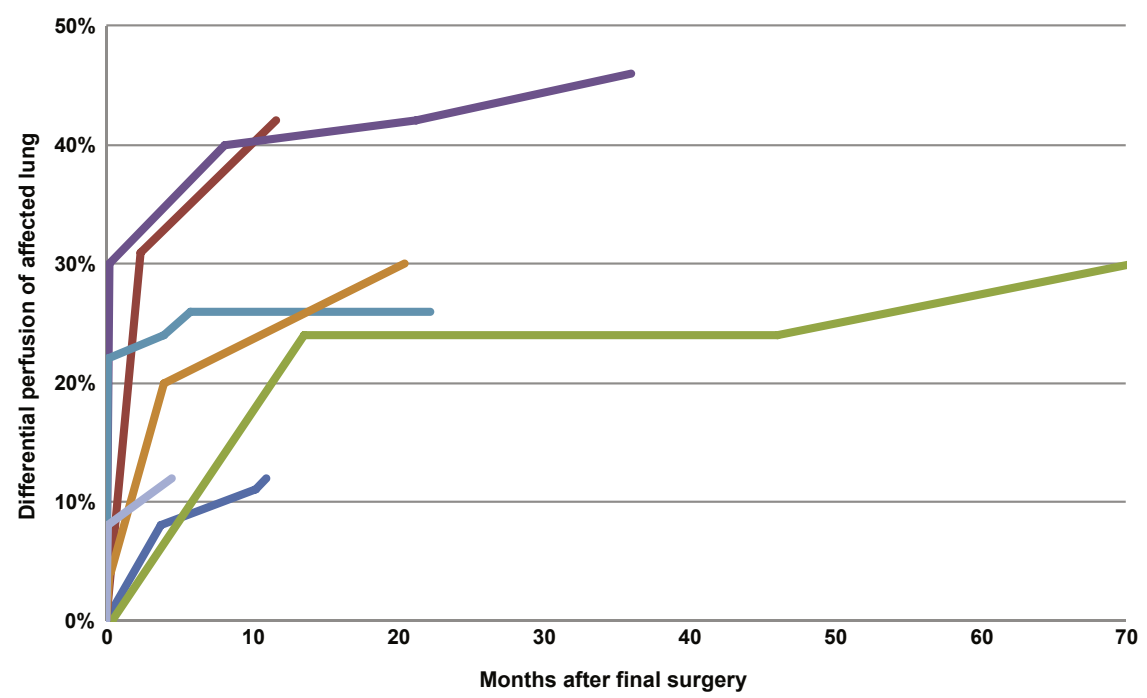

FIGURE 3. Graph showing the increase in differential perfusion of the affected lung as measured by serial radionuclide lung perfusion scans starting at the time of surgery. Each line represents a different patient.

centralizing the abnormal PA with either direct anastomosis $(\mathrm{n}=1)$, anterior pericardial patch augmentation of the anastomosis $(\mathrm{n}=3)$, an interposition autologous pericardial roll $(\mathrm{n}=2)$, or a Gore-Tex interposition graft performed at an outside institution $(\mathrm{n}=1)$. One patient is awaiting his second stage operation (patient 10).

Cardiac catheterization interventions have been required in 3 patients after staged repair. One patient managed with a classic BT shunt and direct anastomosis (patient 1) required angioplasty and stenting of the LPA 10 months after centralization and repeat dilation 5 months later. A patient managed with a modified BT shunt followed by centralization with a pericardial roll (patient 7) required angioplasty and stenting of the RPA 6 months after centralization. Patient 8 , who had undergone ductal stenting as the first stage, had significant kinking of the LPA with poor flow in the immediate postoperative period after centralization. She underwent placement of a stent and required repeat angioplasty 4 months later.

\section{Long-Term Outcomes}

Median follow-up in this cohort was 3.1 years (range, 1 month to 7.9 years). There were no deaths. Recurrent respiratory infections and exercise tolerance improved in all 6 symptomatic patients. Improvement on the radiographic appearance of lung hypoplasia over time was seen in the 5 patients who had lung hypoplasia identified on preoperative chest radiographs, as shown by reduced extent
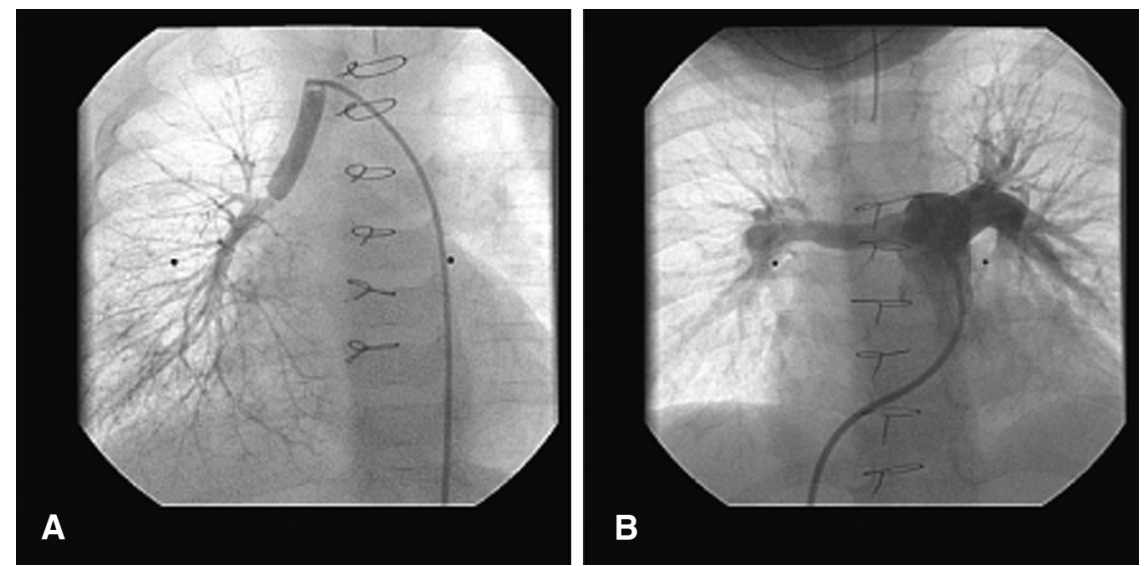

FIGURE 4. Cardiac catheterization images of a patient with ductal origin of the right pulmonary artery (patient 6). A, A cardiac catheterization performed shortly after creation of a modified Blalock-Taussig shunt with cryopreserved vein and revision of the shunt due to thrombosis. The image demonstrates a small right pulmonary artery with stenosis at the distal anastomosis. Balloon angioplasty was delayed for a few weeks because of the fresh anastomosis. B, A follow-up cardiac catheterization performed after centralization of the right pulmonary artery with anterior patch augmentation 9 months later. The image demonstrates a significant increase in the diameter of the native right pulmonary artery after resuscitation. 
of contralateral lung herniation and reduction in the midline shift of mediastinal structures (Figure 2). Among patients undergoing the 2-stage approach, the radiographic improvement was evident after the first stage.

To assess differential lung perfusion, technetium Tc-99m radionuclide lung perfusion scans $(\mathrm{n}=7)$ and phase contrast MRI $(n=4)$ have been obtained after the final surgery (median, 20.5 months; range, 2-70 months) in 7 of the 9 patients in whom centralization has been completed. The median differential perfusion of the affected lung was $26 \%$ (range, $12 \%-46 \%$ ) on radionuclide perfusion scan and $27 \%$ (range, 22\%-42\%) on MRI. Figure 3 shows the progression of differential radionuclide perfusion of the affected lung from the time of final surgery on the 7 patients with available information.

The PA diameter was documented before any intervention (measured by cardiac catheterization or at the time of initial surgical intervention) and after centralization (measured by echocardiography, MRI, or cardiac catheterization) in 6 of the 9 patients in whom centralization has been completed. The diameter of the abnormal PA has increased in size by a median of $3.6 \mathrm{~mm}$ (range, 1.3-5.1 $\mathrm{mm}$ ) after a median follow-up of 28 months (range, 10-70 months) (Figure 4). At last follow-up, the median size of the abnormal PA was $7.7 \mathrm{~mm}$ (range, 4.2-9 $\mathrm{mm}$ ), compared with $9.5 \mathrm{~mm}$ (range, $5-14.2 \mathrm{~mm}$ ) for the contralateral normal PA.

\section{DISCUSSION}

This case series summarizes our experience with resuscitation of the PAs in isolated DOPA. Isolated DOPA is a rare malformation with an incidence of approximately 1 in $200,000 .{ }^{8}$ DOPA is commonly erroneously known as absent pulmonary artery or agenesis of the pulmonary artery. This unfortunate terminology belies the true nature of this condition, which should be more aptly termed ductal origin of the pulmonary artery or absent proximal pulmonary artery. ${ }^{2}$ The embryology of the components of the pulmonary arterial tree is complex ${ }^{9,10}$ : The main PA is derived from the primitive truncus arteriosus by truncal septation, the proximal right and left PAs are derived from the proximal sixth aortic arches bilaterally, and the intrahilar lobar and segmental PAs are derived from the primitive lung buds. The arterial ducts are derived from the distal sixth aortic arches bilaterally. Hence, DOPA occurs when there is involution of the ipsilateral proximal sixth aortic arch with persistent connection between the distal PA and the ductus arteriosus (distal sixth aortic arch). An important corollary is that the intrahilar PA branches form independently and therefore persist despite the involution of the proximal PA. It is presumed that they are normally developed at birth given that they receive blood flow via the patent ductus arteriosus during fetal life.
The misnomer absent PA or agenesis of the PA is unfortunate because it conveys a sense of futility; that nothing can or should be done for an artery that is congenitally absent. A disturbing number of published reports propagate the pervasive but erroneous notion that this lesion is uncorrectable on the basis of the nonexistence of the affected PA; not surprisingly, the patients described in many such reports are never put forth for surgical correction or ultimately undergo pneumonectomy. ${ }^{4,8,11-20}$ In contrast, the term ductal origin of a pulmonary artery clearly conveys that the pulmonary artery is indeed present, but originating from a ductus. The correct understanding of this lesion, and that it is imminently correctable, has been known for many decades. Here we report, as have others, ${ }^{2,21-32}$ evidence that this lesion is clearly amenable to surgical correction by restoring flow to the affected PA.

The first step in the treatment of DOPA is its accurate diagnosis. All the patients in this study underwent cardiac catheterization at the time of diagnosis. The use of cardiac catheterization, and in particular pulmonary vein wedge angiography, is of utmost importance to evaluate the presence and size of the affected PA. Our study demonstrates that if one were to rely on cross-sectional imaging to detect DOPA, several of the patients in this series would have not been identified. Indeed, some of them went undiagnosed for long periods of time despite previous imaging studies. Similarly, cardiac catheterization and intervention with angioplasty and stents play an integral role in the long-term strategy to recruit the affected lung.

In contrast to other series, our study includes only patients who have normal intracardiac anatomy. Patients with complex congenital heart disease, bilateral arterial ductal supply of the PAs, and those with a malformed contralateral lung were excluded with the ultimate goal of understanding what capacity for lung perfusion could be imparted into a lung with ductal origin of its PA in comparison with the contralateral lung that was not congenitally malformed. Furthermore, the documentation on differential perfusion of the lungs at different time points allowed us to quantify the growth and improvement in perfusion of the affected lung with time. Differential perfusion of the affected lung seemed to steadily improve with time, starting at the time of final surgery. Several of these patients required postoperative interventional procedures to supplement the results of centralization. DOPA represents a disease process that requires a multidisciplinary and integral approach between surgical and interventional techniques to achieve optimal results.

In our series, only 2 patients received a single-stage complete repair consisting of creation of a pericardial roll graft between the main PA and the abnormal PA early in our experience. One of those patients has been lost to follow-up and the other developed thrombosis of the graft 
requiring recanalization and stenting in the cardiac catheterization laboratory. Even though this latter patient has gone on to have a good result many years after surgery, we now favor a staged approach to allow adequate growth of the PA before centralization. The first stage includes the creation of an aortopulmonary connection, such as a ductal stent when feasible early in life, or a modified BT shunt if the ductus cannot be crossed with a wire. This seems to be the most reliable and least invasive means of ensuring rapid compensatory growth of the intrapulmonary branches, which otherwise can rapidly become hypoplastic.

The 2 patients in our series who underwent creation of a modified BT shunt with a cryopreserved greater saphenous vein developed early shunt thrombosis requiring revision. It is unclear whether this was secondary to the size of the native abnormal PA that prompted the use of the cryopreserved vein in the first place or whether cryopreserved vein is not an ideal graft for this purpose. Regardless, we have recently favored the use of Gore-Tex grafts for creation of modified BT shunts when ductal stent placement is not possible. We do believe that internal thoracic grafts should play a role for patients with very small PAs.

The smallest PA in our series, resuscitated with a right internal thoracic graft, was $2 \mathrm{~mm}$ in diameter at the initial surgery, but had grown to $5.5 \mathrm{~mm}$ at the time of centralization, indicating that even severely hypoplastic PAs have significant growth potential. Even though the resuscitation procedure becomes more challenging with smaller vessels, the findings of this study have led us to believe that an attempt at resuscitation should be performed for all patients with DOPA, regardless of initial PA size.

In our series, we have used 3 different techniques for centralization: (1) direct anastomosis between the MPA and the isolated PA; (2) the creation of a circumferential pericardial roll to serve as an interposition graft between the MPA and the isolated PA; and (3) a posterior anastomosis between the isolated PA and the MPA with the use of an autologous pericardial patch anteriorly to augment the anastomosis. One patient in our series underwent placement of a Gore-Tex interposition graft at an outside institution as the second-stage procedure. When possible, we favor performing an anastomosis between the isolated PA and the MPA using an anterior patch if necessary, because this technique provides a direct tissue-to-tissue anastomosis that may allow for future growth. $^{29,31}$

Previous series have reported that early diagnosis of DOPA is associated with better outcomes. In a series of 15 patients aged 1 day to 38 months, Kim and colleagues ${ }^{32}$ found that patients treated within the first 6 months of age fared better in terms of differential lung perfusion than those treated late $(42 \%$ vs $25 \%$, respectively). Similarly,
Murphy and colleagues ${ }^{30}$ reported a series of 7 patients with DOPA who were diagnosed by 2 months of age and underwent their first recruitment operation before they were 3 months old. The mean differential perfusion scan of the affected lung was $44 \%$ (range, $22 \%-78 \%$ ).

Our series includes patients aged from 3 days to 9 years old at presentation. We could not find a clear association between age at presentation and outcomes, and contrary to previous reports, ${ }^{32}$ we were able to achieve reasonable results in patients who presented late in childhood (3-9 years) with established lung hypoplasia. All these patients showed significant growth of the hypoplastic lung as shown by chest radiography. The 2 older patients who have had lung perfusion scans to date each have a differential perfusion of $26 \%$, which although lower than that of the contralateral lung, may protect them from development of future complications. Based on our findings, and contrary to some of the recommendations of previous series, we recommend a proactive and stepwise approach to treatment of all patients with DOPA, regardless of age at diagnosis and the initial size of the affected PA.

In conclusion, DOPA is a relatively rare entity and is frequently misdiagnosed, leading to delay in care and/or inappropriate management. The term absent PA contributes to the erroneous understanding of this condition and subsequent treatment, and should be avoided. Patients with DOPA can undergo successful resuscitation of the isolated PA with a combination of interventional and surgical approaches with the goal of improving PA growth and relative blood supply. Early diagnosis and repair helps alleviate associated symptoms and may prevent the long-term sequelae seen in adulthood.

\section{References}

1. Sotomora RF, Edwards JE. Anatomic identification of so-called absent pulmonary artery. Circulation. 1978;57:624-33.

2. Trivedi KR, Karamlou T, Yoo SJ, Williams WG, Freedom RM, McCrindle BW Outcomes in 45 children with ductal origin of the distal pulmonary artery. Ann Thorac Surg. 2006;81:950-7.

3. Atik E, Tanamati C, Kajita L, Barbero-Marcial M. Isolated unilateral pulmonary artery agenesis: evaluation of natural and long term evolution after corrective surgery. Arq Bras Cardiol. 2006;87:423-8.

4. Farghly E, Bousamra M II. Hemoptysis resulting from unilateral pulmonary artery agenesis. Ann Thorac Surg. 2002;74:255-7.

5. Pool PE, Vogel JH, Blount SG Jr. Congenital unilateral absence of a pulmonary artery. The importance of flow in pulmonary hypertension. Am J Cardiol. 1962; 10:706-32.

6. Shakibi JG, Rastan H, Nazarian I, Paydar M, Aryanpour I, Siassi B. Isolated unilateral absence of the pulmonary artery. Review of the world literature and guidelines for surgical repair. Jpn Heart J. 1978;19:439-51.

7. Ten Harkel AD, Blom NA, Ottenkamp J. Isolated unilateral absence of a pulmonary artery: a case report and review of the literature. Chest. 2002;122: 1471-7.

8. Bouros D, Pare P, Panagou P, Tsintiris K, Siafakas N. The varied manifestation of pulmonary artery agenesis in adulthood. Chest. 1995;108:670-6.

9. Apostolopoulou SC, Kelekis NL. Anomalous origin of pulmonary artery from the innominate artery. Pediatr Cardiol. 2004;25:565.

10. Apostolopoulou SC, Kelekis NL, Brountzos EN, Rammos S, Kelekis DA. "Absent" pulmonary artery in one adult and five pediatric patients: imaging, 
embryology, and therapeutic implications. AJR Am J Roentgenol. 2002;179: 1253-60.

11. Simsek PO, Ozcelik U, Celiker A, Yalcin E, Cobanoglu N, Pekcan S, et al. A case of congenital agenesis of the right pulmonary artery presenting with hemoptysis and mimicking pulmonary hemosiderosis. Eur J Pediatr. 2009;168:217-20.

12. Colson DJ, Mortelliti AJ. Management of pediatric hemoptysis: review and a case of isolated unilateral pulmonary artery agenesis. Int J Pediatr Otorhinolaryngol. 2005;69:1161-7.

13. Griffin N, Mansfield L, Redmond KC, Dusmet M, Goldstraw P, Mittal TK, et al. Imaging features of isolated unilateral pulmonary artery agenesis presenting in adulthood: a review of four cases. Clin Radiol. 2007;62:238-44.

14. Gupta K, Livesay JJ, Lufschanowski R. Absent right pulmonary artery with coronary collaterals supplying the affected lung. Circulation. 2001;104:E12-3.

15. Hamdan MA, Abu-Sulaiman RM, Najm HK. Sildenafil in pulmonary hypertension secondary to unilateral agenesis of pulmonary artery. Pediatr Cardiol. 2006;27:279-81.

16. Hassan W, Omrani AA, Neimatallah M, Fadley FA, Halees ZA. Dysphagia lusoria caused by aberrant right subclavian artery, Kommerell's diverticulum, legamentum ring, right descending aorta, and absent left pulmonary artery: a report of a unique vascular congenital disease undetected until adulthood and a review of the literature. Pediatr Cardiol. 2005;26:851-5.

17. Heper G, Korkmaz ME. High-pressure pulmonary artery aneurysm and unilateral pulmonary artery agenesis in an adult. Tex Heart Inst J. 2007;34:425-30.

18. Kochiadakis GE, Chrysostomakis SI, Igoumenidis NE, Skalidis EI, Vardas PE. Anomalous collateral from the coronary artery to the affected lung in a case of congenital absence of the left pulmonary artery: effect on coronary circulation. Chest. 2002;121:2063-6.

19. Ohtsuka T, Nomori H, Watanabe K, Kaji M, Ebihara A, Naruke T, et al. Isolated unilateral absence of a pulmonary artery treated by pneumonectomy in an adult: report of a case. Surg Today. 2006;36:525-7.

20. Rafiei P, Roda MS, Patel RB. Isolated unilateral absence of the right pulmonary artery. South Med J. 2011;104:276-7.
21. Alison M, Garel L, Bigras JL, Dery J, Lapierre C. Unilateral absence of pulmonary artery in children: bronchovascular anatomy, natural course and effect of treatment on lung growth. Pediatr Radiol. 2011;41:459-68.

22. Butera G, Santoro G, Calabro R, Carminati M. Percutaneous treatment of ductal origin of the distal pulmonary artery in low-weight newborns. J Invasive Cardiol. 2008;20:354, 356

23. Cox D, Quinn R, Moran A, Donnelly J. Ductal origin of the pulmonary artery in isolation: a case series. Pediatr Cardiol. 2010;31:997-1001.

24. Green GE, et al. Surgical correction of absence of proximal segment of left pulmonary artery. Circulation. 1968;37:62-9.

25. Krammoh EK, Reppert EH, Cohlan SQ, Spencer FC. Therapeutic strategies in children with an isolated unilaterally absent proximal pulmonary artery. Pediatr Cardiol. 2010;31:607-10.

26. Presbitero P, et al. Absent or occult pulmonary artery. Br Heart J. 1984;52: $178-85$.

27. Sreeram N, Asante-Korang A, Ladusans E. Distal ductal origin of the right pulmonary artery: prospective diagnosis and primary repair in infancy. Int J Cardiol. 1992;35:272-4.

28. Toews WH, Pappas G. Surgical management of absent right pulmonary artery with associated pulmonary hypertension. Chest. 1983;84:497-9.

29. Welch K, Hanley F, Johnston T, Cailes C, Shah MJ. Isolated unilateral absence of right proximal pulmonary artery: surgical repair and follow-up. Ann Thorac Surg. 2005; 79:1399-402.

30. Murphy DN, Winlaw DS, Cooper SG, Nunn GR. Successful early surgical recruitment of the congenitally disconnected pulmonary artery. Ann Thorac Surg. 2004;77:29-35.

31. Kosaka Y, Kurosawa H, Hoshino S, Shin'oka T, Isomatsu Y, Tsuji Y. Surgery for unilateral absence of pulmonary artery using autologous tissue. Ann Thorac Surg. 2003;76:1281-3.

32. Kim GB, Ban JE, Bae EJ, Noh CI, Kim WH, Lee JR, et al. Rehabilitation of pulmonary artery in congenital unilateral absence of intrapericardial pulmonary artery. J Thorac Cardiovasc Surg. 2011;141:171-8. 


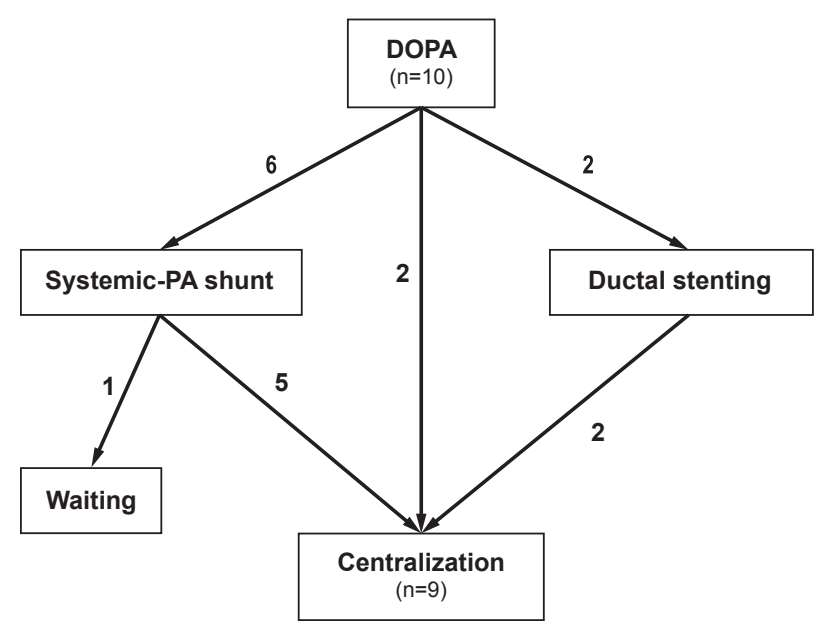

FIGURE E1. The management strategy of the 10 patients with isolated ductal origin of a pulmonary artery (DOPA) in the current series. Centralization of the pulmonary artery $(P A)$ has been achieved in 9 patients either by a single procedure or in a staged fashion by undergoing ductal stenting or creation of a systemic to pulmonary arterial shunt before centralization. 